\title{
Economic aspects of consumer behavior in tourism for a selected population group in the Czech Republic
}

\author{
Miroslava Navrátilová \\ Czech University of Life Sciences in Prague, Prague, Czech Republic, e-mail: navratilovam@pef.czu.cz \\ Markéta Beranová \\ Czech University of Life Sciences in Prague, Prague, Czech Republic, e-mail: mberanova@pef.czu.cz \\ Luboš Smutka \\ Czech University of Life Sciences in Prague, Prague, Czech Republic, e-mail: smutka@pef.czu.cz \\ Lucie Severová \\ Czech University of Life Sciences in Prague, Prague, Czech Republic, e-mail: severova@pef.czu.cz
}

Citation: Navrátilová, M., Beranová, M., Smutka, L., Severová, L. (2020). Economic aspects of consumer behavior in tourism for a selected population group in the Czech Republic. Terra Economicus, 18(4), 149-168. DOI: 10.18522/2073-6606-2020-18-4-149-168

Tourism is currently an important branch of the global economy. However, the democratization of travel and tourism, together with the intensifying globalization processes and mass movements of the world's population, brings with it some accompanying adverse effects that influence the shape of the contemporary world. The paper aims to evaluate the impact of the security and safety factor on the consumer behavior of young people aged 19-29 in the Czech Republic when choosing a destination for tourism. The age categorization was carried out concerning the theoretical definition of youth travel participants according to UNWTO and WYSE Travel Confederation. Attitudes and opinions of the monitored group of consumers were gathered through primary research attended by 428 respondents. Quantitative studies were used to obtain the necessary data using a questionnaire technique of data collection. The results show that, in terms of general preferences, the vast majority of respondents prefer an active way of spending time during their trips. The results show that young people consider the situation in their place of residence as the most important safety factor when choosing a destination (84.8\%); the local political situation and potential health risks in the country are considered as significant ones by less than $70.0 \%$ persons. The majority of respondents (65.7\%) identified the Internet as the predominant way of obtaining information when traveling. travel

Keywords: consumers; coronavirus; destination; health issue; security and safety; surety tourism; youth

Acknowledgements: This work was supported by the Internal Grant Agency of Faculty of Economics and Management, Czech University of Life Sciences Prague - grant number 20181015 "The Impact of Climate Change on the Structure of Agricultural Production in the Czech Republic".

JEL codes: D11, F52, Z32 


\title{
Экономические аспекты потребительского поведения в туризме для выбранной группь населения в Чешской Республике
}

\author{
Мирослава Навратилова \\ Чешский университет естественных наук в Праге, Прага, Чешская Республика, e-mail: navratilovam@pef.czu.cz
}

\section{Маркета Беранова}

Чешский университет естественных наук в Праге, Прага, Чешская Республика, e-mail: mberanova@pef.czu.cz

\author{
Любош Смутка
}

Чешский университет естественных наук в Праге, Прага, Чешская Республика, e-mail: smutka@pef.czu.cz

\section{Люцие Северова}

Чешский университет естественных наук в Праге, Прага, Чешская Республика, e-mail: severova@pef.czu.cz

Цитирование: Navrátilová, M., Beranová, M., Smutka, L., Severová, L. (2020). Economic aspects of consumer behavior in tourism for a selected population group in the Czech Republic. Terra Economicus, 18(4), 149-168. DOI: 10.18522/2073-6606-2020-18-4-149-168

В настоящее время туризм является важной отраслью мировой экономики. Однако демократизация путешествий и туризма, вместе с усиливающимися процессами глобализации и массовыми перемещениями населения мира, влечет за собой некоторые сопутствующие неблагоприятные эффекты, которые влияют на облик современного мира. Даная статья оценивает влияние фактора безопасности и защищенности на потребительское поведение молодых людей в возрасте 19-29 лет в Чешской Республике при выборе их направлений для путешествий. Возрастная категоризация проводилась в отношении теоретического определения участников молодежных путешествий согласно UNWTO и WYSE Travel Confederation. Отношения и мнения исследуемой группы потребителей были собраны путем первичного исследования, в котором приняли участие 428 респондентов. Для получения необходимого эмпирического материала использовались количественные исследования с применением методики сбора данных с помощью анкет. Результаты нашей работы показывают, что с точки зрения общих предпочтений подавляющее большинство респондентов предпочитают активный способ проведения времени во время поездок. Кроме того, мы выяснили, что молодые люди считают ситуацию по месту жительства наиболее важным фактором безопасности при выборе места назначения (84,8\%); с местной политической ситуацией и потенциальными рисками для здоровья в стране считаются менее 70\% человек. Большинство респондентов (65,7\%) определили Интернет как преобладающий способ получения информации во время путешествий.

Ключевые слова: потребители; коронавирус; место назначения; проблема со здоровьем; охрана и безопасность; поручительский туризм; молодежное путешествие

Благодарность: Исследование выполнено при поддержке Агентства внутренних грантов факультета экономики и менеджмента Чешского университета естественных наук в Праге - грант № 20181015 «Влияние изменения климата на структуру сельскохозяйственного производства в Чешской Республике». 


\section{Introduction}

The tourism industry is currently ranked among dynamically developing sectors within the global economy, which, due to its interdisciplinarity, affects all sectors of the economy. At the same time, its strong ties to other sectors make it particularly vulnerable to change in the climates of all spheres of economic, political and social life around the world.

For citizens of economically advanced parts of the world who have enough free time and financial resources, travelling is a natural part of life and one of the ways to spend holidays and relax, but also to realize wishes and gain new experiences and knowledge. For all destinations in the world, tourism and hospitality services are an economic gain and a source of jobs in attractive tourist destinations. For some developing countries, tourism revenue is the backbone of the national economy and is the primary source of funding for its people. It is no exaggeration to say that travelling has never been a phenomenon as widespread as it is today, and the world has never been so closely connected. In connection with tourism and the large movements of the world population during travel, issues associated with the accompanying influences of this phenomenon come to the fore. These, among others, include security and safety issues in a globalized world. Widely discussed challenges include the sustainability of the planet and the degradation of the environment due to tourism.

On this basis, it can be stated that the tourism industry, in some way, affects all destinations and the population of the whole world. The rapid economic and social development of society is accompanied, among other things, by changes in the demographic structure of the population of developed countries, which directly affects the form of demand in the field of tourism. The requirements of potential customers on the character of the product as a whole and as an individual service are changing. It is also possible to observe preference changes in leisure time spending and searching for new attractive destinations. All this creates the need for more precise segmentation of the tourism market.

The young generation is a specific consumer group whose travel preferences already significantly reshape the current form of tourism. Shortly, due to its economic strength, this generation will become the primary source of income in the tourism industry. Understanding the needs, opinions, motivation, behavior and preferences of young people is therefore of great importance for all the players in tourism.

Our paper aims to evaluate the impact of the security and safety factor on the consumer behavior of young people aged 19-29 in the Czech Republic when choosing a travel destination for their tourist trips.

\section{Theoretical background}

The direct contribution of travel and tourism to global GDP amounted to just under 2.89 billion U.S. dollars in 2019, and the total contribution to GDP worldwide in 2019 was just over 9.26 billion U.S. dollars. These figures represent an increase of approximately $60.0 \%$ in both cases compared to $2009^{1}$.

Internationally, borders between countries have been loosening in recent years, which is reflected in minimizing barriers to the movement of people and capital (Rohan, Moravec, 2017). An important role for travel in the European context from this perspective assumes the Schengen Area that allows free movement of E.U. citizens (European Commission, 2018). Strong sanitary and health conditions and a good level of security are a major competitive advantage for most European countries in travel and tourism (World Economic Forum, 2017). Diverse natural conditions and various cultural assets, together with a high level of care for the environment, provide a quality framework for the realization of tourism (Vasylchak, Halachenko, 2016; Löwe et al., 2019; World Economic Forum, 2019). E.U. member states focused its much attention to the conditions for sustainable development (Veveris et al., 2019; Veselá et al., 2018; Hrabánková, Boháčková, 2009).

For tourism in a particular place or country, the existence of historical, cultural or natural attractions is a prerequisite. Each tourism region has a specific potential, which is closely linked mainly with accommodation and catering services, and together they form a quality framework for the stay of potential visitors. The issue of optimum balance in terms of tourism effect and preservation of the character of the destination is currently one of the fundamental questions that the tourism industry is facing.

Statista (2020). Direct and total contribution of travel and tourism to the global economy from 2006 to 2019. New York: Statista (https:// www.statista.com/statistics/233223/travel-and-tourism--total-economic-contribution-worldwide - accessed March 5 2020). 
In tourism, the term tourist destination is used to describe a specific territory. In addition to the traditional tourist destinations, the tourism market is continually generating new areas of tourist interest (Chiabai et al., 2014). Bieger and Beritelli (2013) reflect on a more precise definition of the spatial dimension of the destination, and they believe that the destination is the place the visitor chooses as a target point or as a product. In a broader sense, a country, region, human settlements and other areas characterized by a high concentration of attractions, advanced services and other infrastructure, resulting in a sizeable long-term concentration of visitors, can be considered as a destination. In a narrower sense, a destination can be identified as a target location in a given region, which is characterized by a significant offer of tourist attractions and services (Bieger, Beritelli, 2013). In the literature, it is possible to encounter different typologies of destinations (cf. Buhalis, 2000; Laws, 1995). Haughland et al. (2011) consider a complex integrated approach to be central to addressing destination development. Butler (2006) draws attention to the limited resource capacity of the destination territory. Papatheodorou (2006) states that destination choice has always been an important aspect in tourism literature, and various factors influence travel decisions (Mansfeld, Pizam, 2006). Weaver et al. (2009) consider the knowledge and motivation of the participants in tourism as essential factors in the decision-making of the choice of the destination and activities at the site. Leung and Law (2010) emphasize the diversity of their personalities and thus their reactions in the context of travellers' motivation.

Botero et al. (2013) believe that safety is the most crucial factor in people's choice of destination in the European area. This is also confirmed by Hau and Omar (2014: 1831), who state that: "the service quality component which is destination image, destination support services and security, destination cleanliness and destination facilities, is significantly and positively related to tourist satisfaction". Greater knowledge and awareness about the destination reduces the negative effect of security threats on inbound tourism (Fourie, Rosselló-Nadal, Santana-Gallego, 2019).

Scott, Laws and Prideaux (2008) draw attention to the fact that each destination may find itself in a particular unpredictable crisis due to adverse conditions. The subjective feeling of danger and endangerment of an individual at the place of stay may contribute to the formation of a negative image of destination (Alvarez, Campo, 2014; Donaldson, Ferreira, 2009). However, safety concerns do not only affect the individual's decision-making in tourism. But it also plays a role in strengthening economic and political confidence in the wider environment (Hall, Timothy, Duval, 2004).

Ingram, Taberi and Watthanakhomprathip (2013) believe that the unattractiveness of the destination is predictable through the primary factors they consider actual events and the secondary factors they identify with potential events. "The tourism literature identifies five critical tourism risk factors significantly impacting the choice of destination as follows: (1) War and political instability (2) Health concerns (3) Crime (4) Terrorism and (5) Natural disaster" (Abukhalifeh et al., 2018).

Concerns about poor health, hygiene, security and safety conditions may have an impact on demand generation and may also harm foreign investment in travel and tourism in the country (World Economic Forum, 2019). Terrorist attacks, local war conflicts, epidemics or natural disasters have an impact on the travel and tourism sector which shows a high level of vulnerability in this area (Brondoni, 2016; Pantano, Pietro, 2013; Tarlow, 2011; World Tourism Organization and International Labour Organization, 2013). Mawby (2014) adds that high crime, low-level public disorder and political instability in the country also have a negative impact on tourism. Security and safety has become a complex multidimensional notion with a wide range of components (Kovári, Zimányi, 2011).

One of the fundamental rights of the tourist is the right to be safe and secure from crime, terrorism and disease (World Tourism Organization, 1996). The terms safety and security are not defined in a uniform way in theory of tourism. Both terms are usually used together (Tarlow, 2014; Kovári, Zimányi, 2011). Wichasin and Doungphummes (2012) emphasize that the concepts of safety and security are usually used interchangeably. Ministry of Foreign Trade and Tourism of Peru² defines these terms subsequently.

- "Safety is the set of precautions put in place to prevent tourists and industry workers from being exposed to situations where they believe that they are in personal danger, due to crime, accidents, and emergencies".

\footnotetext{
Ministry of Foreign Trade and Tourism of Peru (2016). Project to enhance the understanding of the factors that explain Destination Competitiveness: Progress Report to the UNWTO Committee on Tourism and Competitiveness. Lima: Ministry of Foreign Trade and Tourism of Peru, p. 22 (https://www.mincetur.gob.pe/wp-content/uploads/documentos/turismo/publicaciones/CTC_ALTA.pdf accessed January 15 2020).
} 
- "Security is the set of precautions put in place against hostile acts that seek to inflict a large scale of damage resulting in maximum economic disruption or measures taken to guard against espionage or sabotage, crime, attack or escape".

Tarlow (2014: 14) says that in practice, security is seen as "protection of person, place, thing, reputation or economy against someone (or someone's tool) that seek to harm". Safety is defined as "the protecting of people (or places, things, reputations, or economies) against unintended consequences of an involuntary nature". The author introduces the term tourism surety, which is a combination of both terms (Tarlow, 2014). Payam (2015) stresses the fact that security in tourism currently includes not only security at the destination of the stay, but also all visitor activities throughout their travel. Brondoni (2016) defined the key issue of global tourism safety and security management as follows (see Table 1).

Table 1

Global safety and security management key issues

\begin{tabular}{|c|c|}
\hline Tourism safety & Tourism security \\
\hline Tourist safety & Tourist security \\
\hline Hotel safety & Hotel security \\
\hline Safety-seeking travellers & Security \& protection of travellers \\
\hline Safety of tourism facilities & Security of outgoing travellers \\
\hline Food safety precautions & Visitor's personal security \\
\hline Site (destination) safety & Security legislation \\
\hline Safety standards & Security agreements \\
\hline Hotel international fire safety practices & Aviation security conventions \\
\hline Fire safety codes \& regulations & Air transport security measures \\
\hline Traffic safety & Airport security measures \\
\hline Public safety & Control of security \\
\hline Safety of maritime navigation & Security personnel \\
\hline Public safety requirements & Private security companies \\
\hline Safety colours \& safety signs & Visible \& invisible security \\
\hline Safety alarms \& devices & Data bases on security \& risks \\
\hline
\end{tabular}

Source: Brondoni, 2016: 12.

Key factors for improving security and safety in tourism can be considered as protection areas and tourist facilities, the reliability of the responsible authorities and trust-building campaigns (Paunović, 2013; World Economic Forum, 2013).

Violence and tourism go hand in hand, whether they are incidental crime or terrorist acts (Ryan, 1993). The main aim of terrorism is to attack rather than individual efforts to strengthen ideological ideas by means of a message addressed to the wider society (Chowdhury, Raj, 2018). Tourism and terrorism in some ways reflects the deep conflicts of the modern world (Korstanje, Clayton, 2012).

World epidemics or pandemics are not new to humanity (Rushton, 2019). The spread of infectious diseases in history was always associated with the movement of people (Abukhalifeh et al., 2018). In 1918 influenza pandemic killed approximately 50 million, HIV/AIDS has claimed more than 35 million lives (Commission on a Global Health Risk Framework for the Future, 2016). In the past 30 years worldwide epidemic increase in the number of events of diverse nature. It can assume that this trend will continue (Frieden et al., 2014). Traveling on a massive scale, it can become an important factor in shaping the form and frequency of diseases in different geographic areas (Abukhalifeh et al., 2018).

Increasing globalization of tourism is linked to public health crises (Richter, 2003). The concept of health and safety in recent years has gained an international dimension (Rokvic, Jeftic, 2015), and there is a growing need for international cooperation (Richter, 2003). Protecting the health and safety of people is also one of the main responsibilities of the government of each state (Frieden et al., 2014). Health problems are a threat to national and global security (Rokvic, Jeftic, 2015). Ravi et al. (2019) draw attention to the importance of regular and sustainable monitoring of the develop- 
ment of health security capabilities and capacities over time in the context of eliminating sources of health insecurity. Hitchcock et al. (2007) attach great importance to global surveillance of outbreaks of infectious diseases and the importance of this activity for international health.

The issue of general health in tourism is monitored from various points of view. Health aspects of tourism were dealt by Clift (1999) which pointed out the health risks of an increased number of tourists traveling to tropical destinations. Bauer (2008) examined the possible health impacts of tourism on the population in tourist destinations. Specific infections that pose potential risks for travelers include: SARS-CoV, MERS-CoV, Chikungunya virus, dengue fever, influenza, Ebola virus or Zika virus (Abukhalifeh et al., 2018). Detailed overview of emerging and reemerging infectious-disease outbreaks, epidemics, and pandemics in the years 2002-2015 can be seen in the following figure (see Fig. 1).

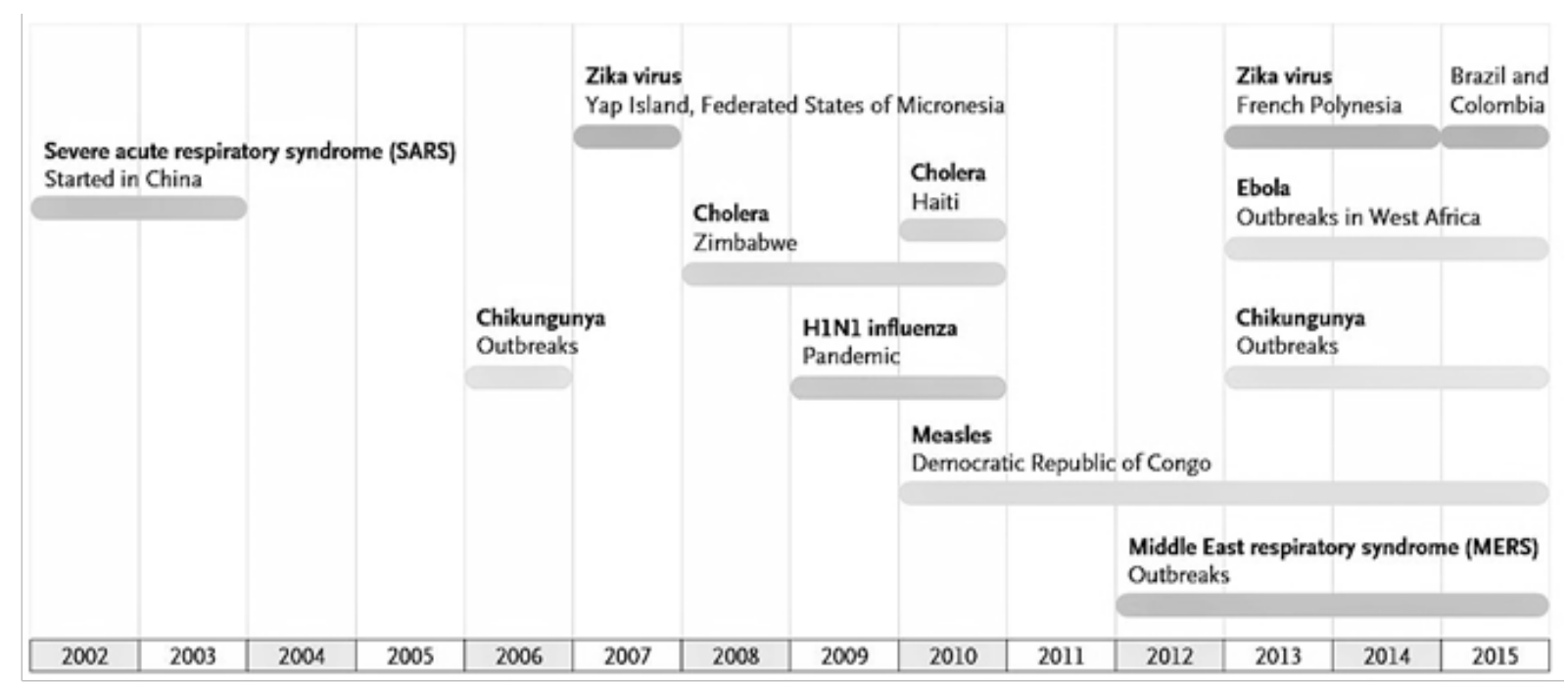

Fig. 1. Major Emerging and Reemerging Infectious-Disease Outbreaks,

Epidemics, and Pandemics, 2002 through 2015

Source: Sands, Mundaca-Shah, Dzau, 2016: 1281.

At the beginning of 2020, the health factor affecting all sectors comes first. One of the most vulnerable sectors will be tourism. Coronavirus COVID-19 is spreading worldwide. World Health Organization defines the disease subsequently: "Coronaviruses are a family of viruses that range from the common cold to MERS coronavirus, which is Middle East Respiratory Syndrome coronavirus and SARs, Severe acute respiratory syndrome coronavirus" ${ }^{\prime 3}$. According to World Health Organization ${ }^{4}$, on 14 September 2020 confirmed globally 28918900 people are infected. This day (14.9.2020), there were 922252 deaths worldwide due to the infection of this virus.

Each generation group is influenced by the shared historical and social life experiences that shape it and which thus distinguish one generation from another. Account should be taken of the specific developments and specific events taking place in individual countries or regions over time (Exenberger, Bucko, 2020; Tyslová et al., 2020; Akhavan Sarraf, 2019; Bernini, Cracolici, 2015). Over time, there has been significant diversification in the tourism sector, as well as significant changes in consumer behavior in tourism as a result of the shift in tourist generations that are vital in tourism.

Today's young generation is a specific group that is of importance to many interest groups, both commercial and scientific. Given the ongoing globalization processes and rapid technological developments, this generation is called the first homogeneous generation worldwide. Despite certain general characteristics of today's young people, it is necessary to take into account the differences that arise from different religious and political backgrounds, specific social customs, social ties and economic conditions of different countries, cultures or continents (Richards, Morrill, 2020; Šimpachová Pechrová et al., 2018; Expedia Group, 2016).

\footnotetext{
3 World Health Organization (2020a). What is coronavirus? Geneva: World Health Organization (https://www.who.int/docs/defaultsource/sri-lanka-documents/what-is-coronavirus-english.pdf?sfvrsn=a6b21ac 2 - accessed March 10 2020).

4 World Health Organization. (2020b). Data as reported by national authorities by 10AM CET September 2020 Coronavirus disease (COVID-19): Dashboard, 2020. Geneva: World Health Organization (https:/covid19.who.int/ - accessed September 14 2020).
} 
Most millennials are now fully-fledged adults who, as young consumers, influence the shape of the market ${ }^{5}$. According to Veiga et al. (2017), it was this generation that has caused the most significant changes in the functioning of the tourism sector in the world. Leask, Fyall and Barron (2013) also agree with this view, demonstrating that trends and future changes in tourism can be predicted based on the current behavior of young consumers. Veríssimo and Costa (2018) add that at present young people's priorities in all areas of their lifestyles, and hence their travel behavior is given considerable attention.

Young consumers are a very unpredictable group in terms of decision-making and purchasing habits, characterized by a low degree of loyalty (Bochert, Cismaru, Foris, 2017) ${ }^{6}$ and continuously confronted with a wide variety of products (Veríssimo, Costa, 2018). This represents a significant challenge for businesses and providers of tourism and hospitality services. However, appropriately applied marketing tools can become a competitive advantage in operating in the youth-oriented tourism market (Ketter, 2020).

The definition and categorization of youth varies from one geographical area to another and in some cases, overlaps occur. The definition of youth travel according to UNWTO and WYSETC (2011) states that: "youth travel includes all independent trips for periods of less than one year by people aged 16-29 which are motivated partly or fully, by a desire to experience other cultures, build life experiences and/or benefit from formal and informal learning opportunities outside one's usual environment".

Youth travel market is considered one of the most important tourism markets. Young travellers get their first travel experience that can potentially affect their future travel behavior (Eusébio, Carneiro, 2015) and have enough free time (Veríssimo, Costa, 2018). Young customers are also an important group in terms of market segmentation in the hospitality industry. According to Lžičař, Rubáček and Abrhám (2019), the hotel industry provides a specific type of service, for the sale of which plays an important role, among other things, seasonality factor and type of distribution channel. In the context of hospitality, it is also necessary to take into account the different dietary habits and requirements of individual groups of travellers for catering facilities (Kročil, Pospísil, 2017). Parment (2013) reports that Y-generation members learn about shops and restaurants and share their experiences with other peers, usually through social networks.

The youth travel market is primarily made up of educational tourism (Moisa, 2010). The importance of traveling during the educational process is confirmed by the research of the Student \& Youth Travel Association ${ }^{7}$, which deals with the social and economic impacts. Results of this research show that more than $75.0 \%$ educators believe that traveling has a positive influence on the personal development of students and considers it important to expand cultural horizons. Approximately $56.0 \%$ of teachers think that travel has a positive impact on education and career. Young people themselves see travel as an opportunity to grow and gain experience ${ }^{8}$. Young millennials very often also prefer volunteer tourism (Veiga et al., 2017) ${ }^{9}$. Leung and Law (2010) state that the Internet is one of the most important communication channels for tourism and hospitality. According to UNWTO \& WYSETC (2011), young people are fearless, and terrorism, political and civil unrest, disease or natural disasters deter them less likely. The results of Deloitte ${ }^{10}$ show that $57.0 \%$ of the $\mathrm{Y}$ and $\mathrm{Z}$ generation want to travel and see the world.

\section{Research objective and methodology}

The theoretical framework of the article was based on the content analysis of secondary sources taking into account the criteria for examining documents, according to Hendl (2005). These were scientific articles, professional literature and relevant internet resources.

\footnotetext{
Nielsen (2017). Young and ready to travel (and shop): a look at millennial travelers. New York: Nielsen (https://www.nielsen.com/wpcontent/uploads/sites/3/2019/04/nielsen-millennial-traveler-study-jan-2017.pdf - accessed February 25 2020).

6 Ibid.

Student \& Youth Travel Association (2012). Student \& Youth Travel: A compreshive survey of the student travel market. Arlington: Student \& Youth Travel Association (https://syta.org/why-travel-matters/research/ - accessed February 09 2020).

8 Resonance (2018). Future of U.S. Millennial TravelReport: A survey of America's fastest growing tourism demographic. Vancouver, New York, Newport: Resonance (http://media.resonanceco.com/uploads/2018/08/Resonance-2018-Future-of-US-Millennial-Travel-Report1.0.pdf - accessed January 30 2020).

9 See also Deloitte (2019). The Deloitte Global Millennial Survey 2019: Societal discord and technological transformation create a "generation disrupted". New York: Deloitte Touche Tohmatsu Limited (https://www2.deloitte.com/global/en/pages/about-deloitte/ articles/millennialsurvey.html - January 5 2020).

${ }^{10}$ Ibid.
} 
Descriptive and inference statistics tools were used to evaluate the qualitative research and to interpret the results of the questionnaire survey. Contingency tables were used to verify the established null hypotheses using the Pearson $\chi 2$ test (Chen, Cohen, Sackrowitz, 2009). In this paper, Cramer's contingency coefficient was used to determine the dependency strength of quality characteristics.

Primary data were obtained utilizing a quantitative survey using the questionnaire technique of data collection, which took place in the autumn months of 2019. The questionnaire survey was responded by 428 young people aged 19 to 29 years from the whole Czech Republic. The age restriction of respondents was chosen with regard to the definition of youth tourist, according to WYSETC, which defines this group as young people aged 15 to 29 years (UNWTO \& WYSETC, 2011). Given the reality in the Czech Republic, when young people reach their majority at the age of 18 and usually finish their high school education by the age of 19, the lower age limit has been moved to 19 . The age categorization was chosen according to Cavagnaro and Staffieri (2015), who point out that the views and motivations of youth travellers can be best observed if the travel choice is entirely up to the individual's decision and not on their parents or guardians. The monitored age category corresponds in the literature to the generation $\mathrm{Y}$ or the millennium generation. The age of respondents was further divided into two categories, 19-24 years and 25-29 years, concerning the classification according to the Czech Statistical Office $^{11}$. The basic socio-demographic characteristics of respondents are summarised in the following table (Table 2).

Table 2

Socio-demographic characteristics of respondents in absolute and relative values

\begin{tabular}{|c|c|c|c|}
\hline \multicolumn{2}{|c|}{ Basic socio-demographic characteristics } & Absolute & Relative \\
\hline \multirow{2}{*}{ Sex } & Males & 183 & 42.8 \\
\hline & Females & 245 & 57.2 \\
\hline \multirow{2}{*}{ Age group } & $19-24$ years & 191 & 44.6 \\
\hline & $25-29$ years & 237 & 55.4 \\
\hline \multirow{5}{*}{ Highest education level } & Lower secondary & 4 & 0.9 \\
\hline & Upper secondary & 27 & 6.3 \\
\hline & Post-secondary & 229 & 53.5 \\
\hline & Short-cycle tertiary & 9 & 2.1 \\
\hline & Tertiary & 159 & 37.1 \\
\hline \multirow{14}{*}{ Permanent residence } & Central Bohemian region & 92 & 21,5 \\
\hline & Hradec Králové region & 17 & 4.0 \\
\hline & Karlovy Vary region & 15 & 3.5 \\
\hline & Liberec region & 9 & 2.1 \\
\hline & Moravian-Silesian region & 7 & 1.6 \\
\hline & Olomouc region & 4 & 0.9 \\
\hline & Pardubice region & 13 & 3.0 \\
\hline & Plzeň region & 8 & 1.9 \\
\hline & Prague & 185 & 43.2 \\
\hline & South Bohemian region & 28 & 6.5 \\
\hline & South Moravian region & 6 & 1.4 \\
\hline & Ústí nad Labem region & 21 & 4.9 \\
\hline & Vysočina region & 18 & 4.2 \\
\hline & Zlín region & 5 & 1.2 \\
\hline
\end{tabular}

Source: Own research, 2019.

\footnotetext{
${ }^{11}$ Czech Statistical Office (2019). Obyvatelstvo. Praha: Český statistický úr̆ad (https://www.czso.cz/csu/czso/obyvatelstvo_lide - accessed February 15 2020).
} 
During the data analysis, the following null hypotheses were tested:

- H01: The choice of the destination, according to the local security situation, does not depend on the respondent's sex.

- H02: The choice of the destination, according to the local security situation, does not depend on the respondent's age.

- H03: The choice of the destination, according to the local political situation, does not depend on the respondent's sex.

- H04: The choice of the destination, according to the local political situation, does not depend on the respondent's age.

- H05: The choice of destination tourist destination concerning potential health risks in the given location does not depend on the respondent's sex.

- H06: The choice of destination tourist destination concerning potential health risks in the given location does not depend on the respondent's age.

In this paper, the following abbreviations are used: E.U. = European Union, MERS-CoV = Middle East Respiratory Syndrome Coronavirus, SARS-CoV = Severe Acute Respiratory Syndrome Coronavirus, UNWTO = United Nation World Tourism Organization, WHO = World Health Organization, WTO = World Tourism Organization, WYSETC $=$ World Youth Student and Educational Travel Confederation.

\section{Results and discussion}

The vast majority of respondents stated that during their travel they prefer an active way of spending their time $(82.5 \%, 353$ persons) over passive rest, which only less than one-fifth of participants $\left(17.5 \%, 75\right.$ persons) stated as their choice. Moreover, a research of Airbnb ${ }^{12}$ shows, that more, then half surveyed millennials prefer active vacation. Null hypotheses about independence not only on sex but also on other independent variables that were determined for this question were tested.

\section{Selection of tourist destination according to the local security situation} concerning the respondent's sex

Table 3

\begin{tabular}{|c|c|c|c|c|c|c|}
\hline $\begin{array}{c}\text { Sex/ } \\
\text { Answer }\end{array}$ & Definitely yes & Rather yes & Rather no & Definitely no & $\begin{array}{c}\text { Do not } \\
\text { know }\end{array}$ & Total \\
\hline Men & 72 & 85 & 21 & 0 & 5 & 183 \\
\hline Women & 104 & 102 & 28 & 6 & 5 & 245 \\
\hline Total & 176 & 187 & 49 & 6 & 10 & 428 \\
\hline \multicolumn{7}{|c|}{ Relative frequencies by sex } \\
\hline Men & $39.3 \%$ & $46.4 \%$ & $11.5 \%$ & $0.0 \%$ & $2.7 \%$ & $100.0 \%$ \\
\hline Women & $42.4 \%$ & $41.6 \%$ & $11.4 \%$ & $2.4 \%$ & $2.0 \%$ & $100.0 \%$ \\
\hline Total & $41.1 \%$ & $43.7 \%$ & $11.4 \%$ & $1.4 \%$ & $2.3 \%$ & $100.0 \%$ \\
\hline
\end{tabular}

Source: 0wn research, 2019.

The calculated value of $\chi^{2} 5.50$ is lower than the critical value of the $\chi 2$ (9.49) distribution with 4 degrees of freedom at the significance level of 0.05 . Therefore, the null hypothesis cannot be rejected, and there was no evidence of dependence between the choice of destination in terms of the local security situation and the gender of the respondent. Based on the results, it can be concluded that the vast majority of respondents consider security in the place of their intended stay as determinant in their travel selection $(84.8 \%, 363)$. Only less than thirteen per cent of respondents chose 'rather not' and 'definitely not', and $2.3 \%$ of respondents did not have a clear stance.

\footnotetext{
${ }_{12}$ Airbnb (2016). Airbnb and The Rise of Millennial Travel. San Francisco: Airbnb, Inc. (https://www.airbnbcitizen.com/wp-content/ uploads/2016/08/MillennialReport.pdf - accessed March 5 2020).
} 
Selection of tourist destination according to the local security situation concerning the respondent's age

\begin{tabular}{|c|c|c|c|c|c|c|}
\hline $\begin{array}{c}\text { Age/ } \\
\text { Answer }\end{array}$ & Definitely yes & Rather yes & Rather no & Definitely no & $\begin{array}{c}\text { Do not } \\
\text { know }\end{array}$ & Total \\
\hline $\mathbf{1 9 - 2 4}$ years & 71 & 91 & 22 & 3 & 4 & 191 \\
\hline $\mathbf{2 5 - 2 9}$ years & 105 & 96 & 27 & 3 & 6 & 237 \\
\hline Total & 176 & 187 & 49 & 6 & 10 & 428 \\
\hline \multicolumn{7}{|c|}{ Relative frequencies by age } \\
\hline $\mathbf{1 9 - 2 4}$ years & $37.2 \%$ & $47.6 \%$ & $11.5 \%$ & $1.6 \%$ & $2.1 \%$ & $100.0 \%$ \\
\hline $\mathbf{2 5 - 2 9}$ years & $44.3 \%$ & $40.5 \%$ & $11.4 \%$ & $1.3 \%$ & $2.5 \%$ & $100.0 \%$ \\
\hline Total & $41.1 \%$ & $43.7 \%$ & $11.4 \%$ & $1.4 \%$ & $2.3 \%$ & $100.0 \%$ \\
\hline
\end{tabular}

Source: Own research, 2019.

The calculated value of $\chi^{2} 2.70$ is lower than the critical value of the $\chi 2$ (9.49) distribution by 4 degrees of freedom at the significance level of 0.05 . Therefore, the null hypothesis cannot be rejected, and it was not possible to prove the dependence between the choice when choosing the destination in terms of the local security situation and the age of the respondent. It can be stated that members of both ages show approximately identical attitudes within the monitored spectrum of opinion.

Selection of tourist destination according to the local political situation

Table 5 concerning the respondent's sex

\begin{tabular}{|c|c|c|c|c|c|c|}
\hline $\begin{array}{c}\text { Sex/ } \\
\text { Answer }\end{array}$ & Definitely yes & Rather yes & Rather no & Definitely no & $\begin{array}{c}\text { Do not } \\
\text { know }\end{array}$ & Total \\
\hline Men & 44 & 83 & 31 & 15 & 10 & 183 \\
\hline Women & 61 & 106 & 57 & 17 & 4 & 245 \\
\hline Total & 105 & 189 & 88 & 32 & 14 & 428 \\
\hline \multicolumn{7}{|c|}{ Relative frequencies by sex } \\
\hline Men & $24.0 \%$ & $45.4 \%$ & $16.9 \%$ & $8.2 \%$ & $5.5 \%$ & $100.0 \%$ \\
\hline Women & $24.9 \%$ & $43.3 \%$ & $23.3 \%$ & $6.9 \%$ & $1.6 \%$ & $100.0 \%$ \\
\hline Total & $24.5 \%$ & $44.2 \%$ & $20.6 \%$ & $7.5 \%$ & $3.3 \%$ & $100.0 \%$ \\
\hline
\end{tabular}

Source: 0wn research, 2019.

The calculated value of statistics $\chi^{2} 7.10$ is lower than the critical value of the distribution $\chi^{2}$ (9.49) by 4 degrees of freedom at the significance level of 0.05 . Therefore, the null hypothesis cannot be rejected. The dependence between the choice of the destination in terms of the local political situation and the sex of the respondent was not proved.

A total of $68.7 \%$ (194) of respondents consider the political situation at the destination of the planned stay as an essential criterion in the choice of the destination. Of the total number of respondents ( $\mathrm{n}=428)$, approximately one quarter identified with the answer "definitely yes" $(24.5 \%, 105)$ and $44.2 \%$ (189) opted for "rather yes". Almost $30.0 \%$ of the participants do not consider the current political situation in the destination to be of greater importance (answers "rather not" $20.6 \%$ and "definitely not" $7.5 \%)$. Men (5.5\%) compared to women (1.6\%) were more likely to have a tie ("I do not know") within individual groups of respondents by sex.

The value of $\chi 29.80$ is higher than the critical value of the $\chi 2(9.49)$ distribution with 4 degrees of freedom at the significance level of 0.05 . The null hypothesis can be rejected. The choice of destination in terms of local political situation therefore depends on the age category to which the re- 
spondent belongs. The dependence measured by Cramer $\mathrm{V}$ is weak $(\mathrm{V}=0.15)$. Significant differences were found by the method of adjusted residuals. The difference between the empirical and theoretical frequencies at the significance level of 0.01 manifested in the "I do not know" answer. This was chosen more often by younger persons (age category 19-24 years), which is due to the authors' less travel experience of this group of respondents due to their lower age. Overall, this answer was chosen least by respondents (only $3.3 \%$ of the total).

\section{Selection of tourist destination according to the local political situation concerning the respondent's age}

Table 6

\begin{tabular}{|c|c|c|c|c|c|c|}
\hline $\begin{array}{c}\text { Age/ } \\
\text { Answer }\end{array}$ & Definitely yes & Rather yes & Rather no & Definitely no & $\begin{array}{c}\text { Do not } \\
\text { know }\end{array}$ & Total \\
\hline $\mathbf{1 9 - 2 4}$ years & 53 & 83 & 41 & 13 & 1 & 191 \\
\hline $\mathbf{2 5 - 2 9}$ years & 52 & 106 & 47 & 19 & 13 & 237 \\
\hline Total & 105 & 189 & 88 & 32 & 14 & 428 \\
\hline \multicolumn{7}{|c|}{ Relative frequencies by age } \\
\hline $\mathbf{1 9 - 2 4}$ years & $27.7 \%$ & $43.5 \%$ & $21.5 \%$ & $6.8 \%$ & $0.5 \%$ & $100.0 \%$ \\
\hline $\mathbf{2 5 - 2 9}$ years & $21.9 \%$ & $44.7 \%$ & $19.8 \%$ & $8.0 \%$ & $5.5 \%$ & $100.0 \%$ \\
\hline Total & $24.5 \%$ & $44.2 \%$ & $20.6 \%$ & $7.5 \%$ & $3.3 \%$ & $100.0 \%$ \\
\hline
\end{tabular}

Source: 0wn research, 2019.

Selection of the tourist destination concerning the potential health risks in the given locality in relation to the respondent's sex

\begin{tabular}{|c|c|c|c|c|c|c|}
\hline $\begin{array}{c}\text { Sex/ } \\
\text { Answer }\end{array}$ & Definitely yes & Rather yes & Rather no & Definitely no & $\begin{array}{c}\text { Do not } \\
\text { know }\end{array}$ & Total \\
\hline Men & 52 & 59 & 48 & 13 & 11 & 183 \\
\hline Women & 93 & 92 & 45 & 10 & 5 & 245 \\
\hline Total & 145 & 151 & 93 & 23 & 16 & 428 \\
\hline \multicolumn{7}{|c|}{ Relative frequencies by sex } \\
\hline Men & $28.4 \%$ & $32.2 \%$ & $26.2 \%$ & $7.1 \%$ & $6.0 \%$ & $100.0 \%$ \\
\hline Women & $38.8 \%$ & $37.6 \%$ & $18.4 \%$ & $4.1 \%$ & $2.0 \%$ & $100.0 \%$ \\
\hline Total & $33.9 \%$ & $35.3 \%$ & $21.7 \%$ & $5.4 \%$ & $3.7 \%$ & $100.0 \%$ \\
\hline
\end{tabular}

Source: 0wn research, 2019.

The value of $\chi 2$ statistic 12.83 is higher than the critical value of the distribution $\chi 2$ (9.49) with 4 degrees of freedom at the significance level of 0.05 . The null hypothesis can be rejected. The choice of the destination concerning the potential health risks in the given location therefore depends on the respondent's sex. The dependence, measured by Cramer $\mathrm{V}$, is weak $(\mathrm{V}=0.17)$. Significant differences were found by the method of adjusted residuals. The difference between the empirical and theoretical frequencies at the significance level of 0.05 was found in the "definitely yes" answer, which was more often chosen by women and in the "I do not know" answer, which was more often chosen by men.

The calculated value of $\chi 23.70$ statistics is lower than the critical value of the $\chi 2$ (9.49) distribution by 4 degrees of freedom at the significance level of 0.05 . Therefore, the null hypothesis cannot be rejected. It was not possible to prove the dependence between the choice of the target destination, considering the potential health risks in the given location and the respondent's age. However, the older age group (25-29) devotes more considerable attention to potential health risks. In this age group, $71.7 \%$ of respondents declared that potential health risks affect their choice of destination. In contrast, $30.9 \%$ of respondents aged 19-24 expressed no interest in this problem. 


\section{Selection of tourist destination concerning potential health risks in the given locality in relation to the respondent's age}

\begin{tabular}{|c|c|c|c|c|c|c|}
\hline $\begin{array}{c}\text { Age/ } \\
\text { Answer }\end{array}$ & Definitely yes & Rather yes & Rather no & Definitely no & $\begin{array}{c}\text { Do not } \\
\text { know }\end{array}$ & Total \\
\hline $\mathbf{1 9 - 2 4}$ years & 59 & 67 & 49 & 10 & 6 & 191 \\
\hline $\mathbf{2 5 - 2 9}$ years & 86 & 84 & 44 & 13 & 10 & 237 \\
\hline Total & 145 & 151 & 93 & 23 & 16 & 428 \\
\hline \multicolumn{7}{|c|}{ Relative frequencies by age } \\
\hline 19-24 years & $30.9 \%$ & $35.1 \%$ & $25.7 \%$ & $5.2 \%$ & $3.1 \%$ & $100.0 \%$ \\
\hline $\mathbf{2 5 - 2 9}$ years & $36.3 \%$ & $35.4 \%$ & $18.6 \%$ & $5.5 \%$ & $4.2 \%$ & $100.0 \%$ \\
\hline Total & $33.9 \%$ & $35.3 \%$ & $21.7 \%$ & $5.4 \%$ & $3.7 \%$ & $100.0 \%$ \\
\hline
\end{tabular}

Source: Own research, 2019.

Gender differences in the views of young travellers were examined by Reisinger and Mavondo (2004). Krajńák and Vágner (2018) on the basis of their research on the opinions of potential Czech tourists on traveling to the Middle East in the context of political-security risks, note significant statistical differences in respondents' answers in terms of gender and age. In the USA, in recent years, the trend of self-travel for women in the younger generation has become a trend for travel, to which some businesses have already fully specialized ${ }^{13}$. Chen, Huang and Chen (2009) also point to different customer preferences, which in their opinion depend on age, family life cycle, highest educational level and household income. Rita, Brochado and Dimova (2019) compiled opinions of millennials from the U.S. and U.K. in terms of their motivation to travel and preference of activities at the destination. Based on their findings, they found that both monitored samples show agreement, but at the same time provide the possibility of segmentation in terms of demographic characteristics. Chen, Huang and Chen (2009) also share the same opinion, considering it essential to examine vacation lifestyle from the perspective of travel behavior in the context of demographic characteristics. Yunusovich (2018) stresses that there is a need to see young consumers in tourism in terms of their preferred travel style. Solo travel has recently become a new phenomenon in youth travel. In this context, the importance of the individual's safety comes to the fore ${ }^{14}$.

As an emerging generation, young people are great advocates of sustainable development (Preko, Doe, Dadzie, 2019), in which they show much higher interest than previous generations. On their travels, millenials appreciate sustainable destinations and products (Bochert, Cismaru, Foris, 2017). Cavagnaro and Staffieri (2015) based on a survey conducted among 18 to 30-year-old students, considered that students' general travel needs were affected by sustainability values. Intensive internationalization of trade during the life of millennials generation leads its members to a sceptical view of the possibility of solving social and economic problems at national level of individual states (Parment, 2013). The authors (e.g., Boháčková, Svatošová, 2012) also draw attention to the importance of international cooperation in the field of sustainability.

It should be noted that, in general, terrorism is considered a major threat within the European Union, less than one fifth (18.0\%) of respondents expressed this opinion in the Eurobarometer survey (European Commission, 2019). Abu Bakar et al. (2018) examined what factors affect the travel plans of young travellers in the context of Islamic tourism. Respondents assigned weight to individual factors on a five-step scale. The answer "safety and terrorism concerns" ranked second in terms of answers, with an average value of 3.96. This suggests that young people are susceptible to this type

\footnotetext{
${ }^{13}$ Resonance (2018). Future of U.S. Millennial TravelReport: A survey of America's fastest growing tourism demographic. Vancouver, New York, Newport: Resonance (http://media.resonanceco.com/uploads/2018/08/Resonance-2018-Future-of-US-Millennial-Travel-Report1.0.pdf - accessed January 302020 ).

${ }^{14}$ Resonance (2018). Future of U.S. Millennial TravelReport: A survey of America's fastest growing tourism demographic. Vancouver, New York, Newport: Resonance (http://media.resonanceco.com/uploads/2018/08/Resonance-2018-Future-of-US-Millennial-Travel-Report1.0.pdf - accessed January 30 2020).
} 
of potential threat and attach great importance to it. Destination security is one of the primary sources of concern for millennials when travelling abroad. In 2017, according to GlobalData research, $63.0 \%$ of young Indonesians said they would probably reconsider their travel destination due to an unstable political situation or a recent terrorist attack at their destination ${ }^{15}$. Current geopolitical unrest means millennials are highly sensitized to security threats ${ }^{16}$. Health and hygiene safety is a priority for millenials when traveling. While the interest in personal safety varies across markets, it is always significantly higher for the Y generation than for previous generations (Expedia Group, 2016).

Furthermore, it was investigated how mostly young people organize their travel (see Table 9) and how much in advance they do so. 62.9\% (269) of the respondents answered that they were planning their trips in a matter of months. Approximately one quarter $(25.9 \%, 111)$ of respondents stated that they make decisions in a matter of weeks. Only 4.9\% (21) of the participants stated that they make decisions impulsively and do not plan at all. Yunusovich (2018) believes that young people plan their journeys carefully and tend to repeat their journeys, increasing the potential of youth travel. Also research of Airbnb ${ }^{17}$ shows that $75.0 \%$ millennials in each country prefer to create their own itinerary.

Table 9

The predominant way of choosing travel realization

\begin{tabular}{|c|c|c|}
\hline Answer & Absolute & Relative \\
\hline $\begin{array}{c}\text { I choose individually through the information on the Internet (air tickets, } \\
\text { accommodation, reservations, review) }\end{array}$ & 281 & $65.7 \%$ \\
\hline $\begin{array}{c}\text { I am looking for information on the offer of guided tours organized by travel } \\
\text { agencies on the Internet }\end{array}$ & 88 & $20.6 \%$ \\
\hline $\begin{array}{c}\text { I make decisions based on the recommendations of friends, acquaintances and } \\
\text { family }\end{array}$ & 39 & $9.1 \%$ \\
\hline I visit branches of travel agencies & 12 & $2.8 \%$ \\
\hline Other & 8 & $1.9 \%$ \\
\hline Total & 428 & $100.0 \%$ \\
\hline
\end{tabular}

Source: 0wn research, 2019.

The results of the questionnaire survey show that the vast majority of respondents $(86.3 \%, 369$ persons) of the total number of respondents $(n=428)$ organize and plan their travel activities in some form via the Internet. Ngelambong et al. (2010) presented similar findings and reported that young people attribute great importance to the Internet as an information medium and most often search for specific websites of direct tourism service providers when planning and organizing their holidays. Tippelt and Kupferschmitt (2015) predict that, due to new technological innovations in communication, more and more classic Internet profile pages will be replaced by direct, immediate form of communication and say that according to their research $80 \%$ of young people aged 14 to 29 use mostly daily Instant Messenger WhatsApp, while Facebook is used by $71 \%$ of respondents in this age category at a lower frequency (Tippelt, Kupferschmitt, 2015). Paris et al. (2015) add that communications technology, mobile use, the internet environment and the creation of virtual communities have transformed the shape of tourism and travel (Strielkowski, 2016; Abrhám, Wang, 2017; or Mitsche, Strielkowski, 2017). Social media is an integral part of the online tourism sector and

\footnotetext{
${ }^{15}$ GlobalData (2018). Millennial Traveler Insights: Understanding the motivations and behaviors of millennial. London: GlobalData (https://www.guyanatourism.com/wp-content/uploads/2018/09/Global-Data-Millennial-Traveller-Insights-2018.pdf $\quad$ - accessed February 22 2020).

${ }^{16}$ Global Blue (2018). Millennials: The generation reshaping travel and shopping habits. Eysins: Global Blue - Group communication \& Editorial (https://www.rolandberger.com/en/Publications/MILLENNIALS-The-generation-reshaping-travel-and-shopping-habits.html accessed March 10 2020).

${ }^{17}$ Airbnb (2016). Airbnb and The Rise of Millennial Travel. San Francisco: Airbnb, Inc. (https://www.airbnbcitizen.com/wp-content/ uploads/2016/08/MillennialReport.pdf - accessed March 5 2020).
} 
provide stakeholders with a wide range of opportunities to communicate and exchange information (Canavan, 2017; Sotiriadis, van Zyl, 2013).

It is, therefore, a vital task for professional tourism services to provide comprehensive and reliable information and services (Rathore, Joshi, Ilavarasan, 2017). In the security context, communication technologies can positively influence an individual's feelings during their journey, especially their perceived problems associated with an increased risk to personal safety and health (Paris et al., 2015). The use of communication technologies on the road also brings its risks. Millennials take technology security issues far more seriously than older generations and realize the security risks associated with data theft or abuse ${ }^{18}$. Sofronov (2018) believes that millennials in the traveling exhibit more responsible behavior than older generations, and it is documented by the fact that approximately half $(49.0 \%)$ of them before traveling purchase travel insurance. Ketter (2020) considers important trends in tourism to young creative tourism, off-the-beaten-track tourism, alternative accommodation and fully digital tourism.

Currently, the world is solving problems associated with the occurrence of Coronavirus, its impacts on the global economy, and this it is not economically possible to express these problems in its entirety (Nikšić Radić, Dragičević, Barkiđija Sotošek, 2018). The health risks of traveling were more likely to be associated with traveling to less developed countries. Some research deals with the impacts of individual epidemic diseases in the context of tourism. The impacts of SARS-CoV are the most frequently studied, with particular attention being paid to Asian countries (Frieden et al., 2014; Mao, Ding, Lee, 2010). The influence of MERS-CoV on the tourism industry has been investigated, e.g., by Joo et al. (2019), avian flu, e.g., by Frieden et al. (2014) or Kuo et al. (2008). The impact of epidemimiological diseases and their negative impact on all areas of society can be considered as proven. Gostin aad Katz (2016) highlight the role of the WHO in the context of global health risks and stress the need for international regulation of this issue.

However, based on the experience of previous decades, it is already possible to anticipate the negative impacts of current events on travel and tourism and other related sectors (Hui et al., 2020; Tarlow, 2020; Tounta, 2020).

\section{Conclusion}

Tourism is currently seen as an inescapable phenomenon that affects both the global economy and the individual national economies of all countries of the world. Progressing globalization processes on the one hand connect the world, but on the other make it more vulnerable. In the context of the current social, political and economic situation, attention should be paid to all the effects of changes in travel and tourism. It is mainly about the expansion of air transport on an unprecedented scale, which is accompanied by a mass population transfer and the associated security and safety risks. In terms of tourism, youth travel is currently the fastest developing segment. Due to the specific requirements of the current young generation in the areas of travel, tourism and hospitality, there are new requirements and tasks for organizations and companies operating in this field. In the context of the sustainability of the planet, the current form of tourism is an up-to-date problem of the whole society.

The paper aims to evaluate the impact of the security and safety factor on the consumer behavior of young people aged 19-29 in the Czech Republic when choosing a destination for tourism. This article presents the results of the primary questionnaire survey, which was attended by 428 respondents in the given age category.

The results show that young people consider the situation in their place of residence as the most important safety factor when choosing a destination (84.8\%), the local political situation and potential health risks in the country are considered to be less than $70.0 \%$ persons. The majority of respondents $(65.7 \%)$ identified the Internet as the predominant way of obtaining information when traveling.

\footnotetext{
${ }^{18}$ Booking.com (2018). How to attend to the needs of your millennial travellers: Travel Trends 2018 Global Survey Report. Amsterdam: Booking.com (https://business.booking.com/lp-how-to-attend-to-the-needs-of-your-millennial-travellers/ - accessed November 19 2019).
} 
The theoretical contribution of this work lies in the processing of security and safety issues in terms of the perception of young travellers within travel and tourism. Practical contribution can be seen in the presentation of the results of primary research - a questionnaire survey. The limiting factor of this contribution may be the fact that the survey was conducted only among respondents of one country. Expected further direction of research is possible to extend the questioning to other states in order to make a comparison. According to the authors of the article, exciting results could also be obtained by repeating the research in connection with current events in the world, which are perceived by the tourism participants as potentially dangerous for their travel.

\section{References}

Abrhám, J., Wang, J. (2017). Novel trends on using ICTS in the modern tourism industry. Czech Journal of Social Sciences, Business and Economics, 6(1), 37-43. https://doi.org/10.24984/ cjssbe.2017.6.1.5

Abu Bakar, B., Tan, E., Nair, S., Lim, T. (2018). Halalfying travel: Reaching for the Muslim millennial travelers, pp. 1-8 / In: Proceedings of the Council for Australasian University Tourism and Hospitality Education (CAUTHE): Conference 2018. Newcastle, New South Wales: The University of Newcastle.

Abukhalifeh, A., Martinez Faller, E., Albattat, A., Salam, T. (2018). Current issue in tourism: Diseases transformation as a potential risks for travellers. Global and Stochastic Analysis, 5(7), 341-349.

Akhavan Sarraf, A. R. (2019). Generational groups in different countries. International Journal of Social Sciences \& Humanities, 4(1), 41-52. https://doi.org/10.5281/zenodo.2562174

Alvarez, M. D., Campo, S. (2014). The influence of political conflicts on the country image and intention to visit: a study of Israel's image. Tourism Management, 40, 70-78. https://doi.org/10.1016/j. tourman.2013.05.009

Bauer, I. (2008). The health impact of tourism on local and indigenous populations in resourcepoor countries. Travel Medicine and Infectious Disease, 6(5), 276-291. https://doi.org 10.1016/j. tmaid.2008.05.005

Bernini, C., Cracolici, M. F. (2015). Demographic change, tourism expenditure and life cycle behaviour. Tourism Management, 47, 191-205. https://doi.org/10.1016/j.tourman.2014.09.016

Bieger, T., Beritelli, P. (2013). Management von Destinationen. München: Oldenbourg Wissenschaftsverlag.

Boháčková, I., Svatošová, L. (2012). Possibilities of effectiveness evaluation of development cooperation of European union. Agricultura Tropica et Subtropica, 45(2), 89-96. https://doi. org/10.2478/v10295-012-0015-6

Bochert, R., Cismaru, L., Foris, D. (2017). Connecting the members of generation Y to destination brands: A case study of the CUBIS project. Sustainability, 9(7), 1197-1217. https://doi. org/10.3390/su9071197

Botero, C., Anfuso, G., Williams, A. T., Zielinski, S., da Silva, C. P., Cervantes, 0. et al. (2013). Reasons for beach choice: European and Caribbean perspectives. Journal of Coastal Research, 65, 880-885. https://doi.org/10.2112/SI65-149.1

Brondoni, S. M. (2016). Global Tourism and Terrorism. Safety and Security Management. Symphonya. Emerging Issues in Management, 2, 7-14. https://doi.org/10.4468/2016.2.02brondoni

Buhalis, D. (2000). Marketing the competitive destination of the future. Tourism Management, 21(1), 97-116. https://doi.org/10.1016/S0261-5177(99)00095-3

Butler, R. W. (2006). The Tourism Area Life Cycle. Vol. 1: Applications and Modifications, Clevedon: Channel View Publications.

Canavan, B. (2017). An existentialist exploration of tourism sustainability: backpackers fleeing and finding themselves. Journal of Sustainable Tourism, 26(4), 551-566. https://doi.org/10.1080/09 669582.2017.1361430 
Cavagnaro, E., Staffieri, S. (2015). A study of students' travellers values and needs in order to establish futures patterns and insights. Journal of Tourism Futures, 1(2), 94-107. https://doi. org/10.1108/JTF-12-2014-0013

Clift, S. (1999). Tourism and Health: Current Issues and Future Concerns. Tourism Recreation Research, 25(3), 55-61. https://doi.org/10.1080/02508281.2000.11014925

Commission on a Global Health Risk Framework for the Future (2016). The neglected dimension of global security: A framework to counter infectious disease crises. Washington, DC: The National Academies Press.

Donaldson, R., Ferreira, S. (2009). (Re-) creating urban destination image: opinions of foreign visitors to South Africa on safety and security. Urban Forum, 20(1), 1-18. https://doi.org/10.1007/ s12132-009-9053-1

European Commission (2018). Special Eurobarometer 474: Europeans' perceptions of the Schengen Area. Brussels: European Commission.

European Commission (2019). Standard Eurobarometer 91 - Spring 2019: Public opinion in the European Union, First results. Brussels: European Commission.

Eusébio, C., Carneiro, M. J. (2015). How diverse is the youth tourism market?: An activity-based segmentation study. Tourism, 63(3), 295-316.

Exenberger, E., Bucko, J. (2020). Analysis of online consumer behavior - Design of CRISP-DM process model. AGRIS on-line Papers in Economics and Informatics, 12(3), 13-22. https://doi.org/10.7160/ aol.2020.120302

Expedia Group (2016). Millennial traveler report: why millennials will shape the next 20 years of travel. Seattle: Expedia Group.

Fourie, J., Rosselló-Nadal, J., Santana-Gallego, M. (2019). Fatal attraction: How security threats hurt tourism. Journal of Travel Research, 59(2), 209-219. https://doi.org/10.1177/0047287519826208

Frieden, T. R., Tappero, J. W., Dowell, S. F., Hien, N. T., Guillaume, F. D., Aceng, J. R. (2014). Safer countries through global health security. The Lancet, 383(9919), 764-766. https://doi. org/10.1016/S0140-6736(14)60189-6

Gostin, L. 0., Katz, R. (2016). The International Health Regulations: The Governing Framework for Global Health Security. The Milbank Quarterly, 94(2), 264-313.

Hall, C. M., Timothy, D. J., Duval, D. T. (2004). Security and tourism: towards a new understanding? Journal of Travel \& Tourism Marketing, 15(2-3), 1-18. https://doi.org/10.1300/J073v15n02_01

Hau, T. C., Omar, K. (2014). The Impact of Service Quality on Tourist Satisfaction: The Case Study of Rantau Abang Beach as a Turtle Sanctuary Destination. Mediterranean Journal of Social Sciences, 5(23), 1827-1832. https://doi.org/10.5901/mjss.2014.v5n23p1827

Haugland, S. A., Ness, H., Grønseth, B-0., Aarstad, J. (2011). Development of tourism destinations. Annals of Tourism Research, 38(1), 268-290. https://doi.org/10.1016/j.annals.2010.08.008

Hendl, J. (2005). Kvalitativní výzkum: základní metody a aplikace. Praha: Portál. (In Czech.)

Hitchcock, P., Chamberlain, A., Van Wagoner, M., Inglesby, T. V., 0’Toole, T. (2007). Challenges to Global Surveillance and Response to Infectious Disease Outbreaks of International Importance. Biosecurity and Bioterrorism: Biodefense Strategy, Practice, and Science, 5(3), 206-227. https:// doi.org/10.1089/bsp.2007.0041

Hrabánková, M., Boháčková, I. (2009). Conditions of sustainable development in the Czech Republic in compliance with the recommendation of the European Commission. Agricultural Econonomics, 55(3), 156-160. https://doi.org/10.17221/980-AGRICECON

Hui, D. S., I Azhar, E., Madani, T. A., Ntoumi, F., Kock, R., Dar, 0. et al. (2020). The continuing 2019$\mathrm{nCoV}$ epidemic threat of novel coronaviruses to global health - The latest 2019 novel coronavirus outbreak in Wuhan, China. International Journal of Infectious Diseases, 91, 264-266. https://doi. org/10.1016/j.ijid.2020.01.009 
Chiabai, A., Platt, S., Strielkowski, W. (2014). Eliciting users' preferences for cultural heritage and tourism-related e-services: A tale of three European cities. Tourism Economics, 20(2), 263-277. https://doi.org/10.5367/te.2013.0290

Chen, C., Cohen, A., Sackrowitz, H. B. (2009). Multiple testing in ordinal data models. Electronic Journal of Statistics, 3, 912-931.

Chen, J. S., Huang, Y-C., Cheng, J-S. (2009). Vacation lifestyle and travel behaviors. Journal of Travel \& Tourism Marketing, 26(5-6), 494-506. https://doi.org/10.1080/10548400903163038

Chowdhury, A., Raj, R. (2018). Risk of terrorism and crime on the tourism industry, pp. 26-34 / In: M. E. Korstanje, R. Raj, K. Griffin (eds.) Risk and Safety Challenges for Religious Tourism and Events. Wallington (United Kingdom): CAB International.

Ingram, H., Tabari, S., Watthanakhomprathip, W. (2013). The impact of political instability on tourism: Case of Thailand. Worldwide Hospitality and Tourism Themes, 5(1), 92-103. https://doi. org/10.1108/17554211311292475

Joo, H., Maskery, B. A., Berro, A. D., Rotz, L. D., Lee, Y.-K., Brown, C. M. (2019). Economic impact of the 2015 MERS outbreak on the Republic of Korea's tourism-related industries. Health Security, 17(2), 100-108. https://doi.org/10.1089/hs.2018.0115

Ketter, E. (2020). Millennial travel: Tourism micro-trends of European Generation Y. Journal of Tourism Futures, 1-5. https://doi.org/10.1108/JTF-10-2019-0106

Korstanje, M. E., Clayton, A. (2012). Tourism and terrorism: conflicts and commonalities. Worldwide Hospitality and Tourism Themes, 4(1), 8-25. https://doi.org/10.1108/17554211211198552

Kovári, I., Zimányi, K. (2011). Safety and security in the age of global tourism (The changing role and conception of safety and security in tourism). Applied Studies in Agribusiness and Commerce, 5(3-4), 59-61. https://doi.org/10.19041/Apstract/2011/3-4/10

Krajňak, T., Vágner, J. (2018). Politicko-bezpečnostní rizika pro cestovní ruch: prostorová percepce Blízkého východu potenciálními českými turisty. Geografie, 123(3), 379-405.

Kročil, 0., Pospíšil, R. (2017). Halal products system audit and its importance for the Czech Republic export strategy. The Journal of Economic Sciences: Theory and Practice, 74(2), 43-50.

Kuo, H.-I., Chen, C.-C., Tseng, W.-C., Ju, L.-F., Huang, B.-W. (2008). Assessing impacts of SARS and Avian Flu on international tourism demand to Asia. Tourism Management, 29(5), 917-928. https://doi. org/10.1016/j.tourman.2007.10.006

Laws, E. (1995). Tourist destination management: issues, analysis, and policies. New York: Routledge.

Leask, A., Fyall, A., Barron, P. (2013). Generation Y: Opportunity or challenge - strategies to engage Generation Y in the U.K. attractions' sector. Current Issues in Tourism, 16(1), 17-46.

Leung, R., Law, R. (2010). A review of personality research in the tourism and hospitality context. Journal of Travel \& Tourism Marketing, 27(5), 439-459. https://doi.org/10.1080/10548408.2010.499058

Löwe, R., Sedmíková, M., Natov, P., Jankovský, M., Hejcmanová, P., Dvořák, J. (2019). Differences in timber volume estimates using various algorithms available in the control and information systems of harvesters. Forests, 10(5). https://doi.org/10.3390/f10050388

Lžičař, P., Rubáček, F., Abrhám, J. (2019). Revenue management in hospitality industry: Case study of a selected congress hotel, pp. 365-374 / In: Conference Proceedings of the 7th International Scientific Conference IFRS: Global Rules and Local Use - Beyond the Numbers. Prague: Metropolitan University Prague.

Mansfeld, Y., Pizam, A. (2006). Tourism Security \& Safety:From Theory to Practice. 0xford: Elsevier.

Mao, C.-K., Ding, C. G., Lee, H.-Y. (2010). Post-SARS tourist arrival recovery patterns: An analysis based on a catastrophe theory. Tourism Management, 31(6), 855-861. https://doi.org/10.1016/j. tourman.2009.09.003

Mawby, R. I. (2014). Crime and Disorder, Security and the Tourism Industry / In: M. Gill (ed.) The Handbook of Security. London: Palgrave Macmillan. 
Mitsche, N., Strielkowski, W. (2017). Tourism e-services and Jewish heritage: A case study of Prague. European Journal of Tourism, Hospitality and Recreation, 7(3), 203-211. https://doi.org/10.1515/ ejthr-2016-0022

Moisa, C. (2010). Aspects of the Travel Demand. Annales Universitatis Apulensis Series Oeconomica, 12(2), 575-582.

Ngelambong, A., Tahir, M. S., Rahman, N., Hadi, A. A. (2010). Demographic profiles of young travelers using the Internet for information search, pp. 1192-1196 / In: 2010 International Conference on Science and Social Research (CSSR 2010). Kuala Lumpur (Malaysia).

Nikšić Radić, M., Dragičević, D., Barkiđija Sotošek, M. (2018).The tourism-led terrorism hypothesis evidence from Italy, Spain, UK, Germany and Turkey. Journal of International Studies, 11(2), 236 249. https://doi.org/10.14254/2071-8330.2018/11-2/16

Pantano, E., Pietro, L. D. (2013). From e-tourism to f-tourism: emerging issues from negative tourists' online reviews. Journal of Hospitality and Tourism Technology, 4(3), 211-227. https://doi. org/10.1108/JHTT-02-2013-0005

Papatheodorou, A. (2006). Managing Tourism Destinations, Northampton: Edward Elgar Publishers.

Paris, C. M., Berger, E. A., Rubin, S., Casson, M. (2015). Disconnected and unplugged: Experiences of technology induced anxieties and tensions while traveling. Information and Communication Technologies in Tourism, 803-816.

Parment, A. (2013). Generation Y vs. Baby Boomers: Shopping behavior, buyer involvement and implications for retailing. Journal of Retailing and Consumer Services, 20(2), 189-199. https:// doi.org/10.1016/j.jretconser.2012.12.001

Paunović, I. (2013). Proposal for Serbian tourism destinations marketing campaign. Singidunum Journal of Applied Sciences, 10(2), 40-52. https://doi.org/10.5937/sjas10-4327

Payam, M. M. (2016). Tourists' security: The need for tourism police in Bosnia and Herzegovina. British Journal of Economics, Management \& Trade, 12(1), 1-9. https://doi.org/10.9734/ BJEMT/2016/23135

Pine, R., McKercher, B. (2004). The impact of SARS on Hong Kong's tourism industry. International Journal of Contemporary Hospitality Management, 16(2), 139-143. https://doi. org/10.1108/09596110410520034

Preko, A., Doe, F., Dadzie, S. A. (2019). The future of youth tourism in Ghana: Motives, satisfaction and behavioural intentions. Journal of Tourism Futures, 5(1), 5-21. https://doi.org/10.1108/ JTF-12-2016-0059

Rathore, A. K., Joshi, U. C., Ilavarasan, P. V. (2017). Social media usage for tourism: A case of Rajasthan tourism. Procedia Computer Science, 3(122), 751-758. https://doi.org/10.1016/j. procs.2017.11.433

Ravi, S. J., Meyer, D., Cameron, E., Nalabandian, M., Pervaiz, B., Nuzzo, J. B. (2019). Establishing a theoretical foundation for measuring global health security: A scoping review. BMC Public Health, 19(1), 1-9. https://doi.org/10.1186/s12889-019-7216-0

Reisinger, Y., Mavondo, F. (2004). Exploring the relationships among psychographic factors in the female and male youth travel market. Tourism Review International, 8(2), 69-84.

Richards, G., Morrill, W. (2020). Motivations of global Millennial travelers. Revista Brasileira de Pesquisa em Turismo, 14(1), 126-139. https://doi.org/10.7784/rbtur.v14i1.1883

Richter, L. K. (2003). International tourism and its global public health consequences. Journal of Travel Research, 41(4), 340-347.

Rita, P., Brochado, A., Dimova, L. (2019). Millennials' travel motivations and desired activities within destinations: a comparative study of the U.S. and the U.K. Current Issues in Tourism, 22(16), 2034-2050. https://doi.org/10.1080/13683500.2018.1439902 
Rohan, J., Moravec, L. (2017). Tax Information Exchange Influence on Czech Based Companies' Behavior in Relation to Tax Havens. Acta Universitatis Agriculturae et Silviculturae Mendelianae Brunensis, 65(2), 721-726. https://doi.org/10.11118/actaun201765020721

Rokvic, V., Jeftic, Z. (2015). Health issues as security issues. Vojno Delo, 67(6), 53-69. https://doi. org/10.5937/vojdelo1506053R

Rushton, S. (2019). Security and Public Health. Oxford: Wiley.

Ryan, C. (1993). Crime, violence, terrorism and tourism. Tourism Management, 14(3), 173-183. https://doi.org/10.1016/0261-5177(93)90018-G

Sands, P., Mundaca-Shah, C., Dzau, V. J. (2016). The Neglected Dimension of Global Security - A Framework for Countering Infectious-Disease Crises. New England Journal of Medicine, 374(13), 1281-1287. https://doi.org/10.1056/NEJMsr1600236

Scott, N., Laws, E., Prideaux, B. (2008). Tourism crises and marketing recovery strategies. Journal of Travel \& Tourism Marketing, 23(2-4), 1-13. https://doi.org/10.1300/J073v23n02_01

Sofronov, B. (2018). Millennials: A new trend for the tourism industry. Annals of Spiru Haret University. Economic Series, 18(3), 109-122. https://doi.org/10.26458/1838

Sotiriadis, M. D., van Zyl, C. (2013). Electronic word-of-mouth and online reviews in tourism services: the use of twitter by tourists. Electronic Commerce Research, 13(1), 103-124. https://doi. org/10.1007/s10660-013-9108-1

Strielkowski, W. (2016). Innovations in tourism marketing: Operation Anthropoid in Prague. Marketing and Management of Innovations, 4, 106-112.

Šimpachová Pechrová, M., Šimpach, 0., Medonos, T., Spěšná, D., Delín, M. (2018). What are the motivation and barriers of young farmers to enter the sector? AGRIS on-line Papers in Economics and Informatics, 10(4), 79-87. https://doi.org/10.7160/aol.2018.100409

Tarlow, P. E. (2011). Tourism disaster management in an age of terrorism. International Journal of Tourism Anthropology, 1(3-4), 18-30. https://doi.org/10.1504/IJTA.2011.043709

Tarlow, P. E. (2014). Tourism Security: Strategies for Effectively Managing Travel Risk an Safety. Waltham, Oxford: Elsevier.

Tarlow, P. E. (2020). In the age of pandemics: Some of the reasons that tourism industries fail: part one of a two-part series (https://www.hotel-online.com/press_releases/release/in-the-age-ofpandemics-some-of-the-reasons-that-tourism-industries-fail-part-one-of-a-two-part-series accessed March 3 2020).

Tippelt, F., Kupferschmitt, T. (2015). Social Web: Ausdifferenzierung der Nutzung - Potenziale für Medienanbieter: Ergebnisse der ARD/ZDF-Onlinestudie 2015. Media Perspektiven, (10), 442-452.

Tounta, P. (2020). Pandemic 2020: The impact on tourism and the shadowy points (https://www. traveldailynews.com/post/pandemic-2020-the-impact-on-tourism-and-the-shadowy-points accessed March 3 2020).

Tyslová, I., Abrhám, J., Horváthová, Z., Rubáček, F. (2020). Economic benefits of tourism: Cultural identity and tourism destinations in the Czech Republic. Terra Economicus, 18(2), 139-154. https://doi.org/10.18522/2073-6606-2020-18-2-139-154

UNWTO \& WYSETC (2011). The Power of Youth Travel, Madrid: World travel organization (UNWT0), Amsterdam: WYSE Travel Confederation.

Vasylchak, S., Halachenko, A. (2016). Theoretical basis for the development of resort services: regional aspect. International Economics Letters, 5(2), 54-62. https://doi.org/10.24984/iel.2016.5.2.3

Veiga, C., Custódio Santos, M., Águas, P., Santos, J. A. C. (2017). Are millennials transforming global tourism? Challenges for destinations and companies. Worldwide Hospitality and Tourism Themes, 9(6), 603-616. https://doi.org/10.1108/WHATT-09-2017-0047

Veríssimo, M., Costa, C. (2018). Do hostels play a role in pleasing Millennial travellers? The Portuguese case. Journal of Tourism Futures, 4(1), 57-68. https://doi.org/10.1108/JTF-12-2017-0054 
Veselá, K., Brož, D., Navrátilová, M., Beranová, M. (2018). Influence of the E.U. and common currency on the structure of foreign commerce, 1425-1432 / In: International Scientific Conference Globalization and Its Socio-Economic Consequences. Rajecke Teplice: University of Zilina.

Veveris, A., Šapolaitė, V., Giedrè Raišienè, A., Bilan, Y. (2019). How rural development programmes serve for viability of small farms? Case of Latvia and Lithuania. AGRIS on-line Papers in Economics and Informatics, 11(2), 103-113. https://doi.org/10.7160/aol.2019.110210

Weaver, P. A., Mc Cleary, K. W., Han, J., Blosser, P. E. (2009). Identifying leisure travel market segments based on preference for novelty. Journal of Travel \& Tourism Marketing, 26(5-6), 568-584. https:// doi.org/10.1080/10548400903163129

Wichasin, P., Doungphummes, N. (2012). A comparative study of international tourists' safety needs and Thai tourist polices' perception towards international tourists' safety needs. World Academy of Science, Engineering and Technology, 67, 1372-1378.

World Economic Forum (2013). The Travel \& Tourism Competitiveness Report 2013: Reducing Barriers to Economic Growth and Job Creation. Geneva: World Economic Forum.

World Economic Forum (2017). The Travel \& Tourism Competitiveness Report 2017: Paving the way for a more sustainable and inclusive future. Geneva: World Economic Forum.

World Economic Forum (2019). The Travel \& Tourism Competitiveness Report 2019: Travel and Tourism at a Tipping Point. Geneva: World Economic Forum.

World Tourism Organization (1996). Tourist Safety and Security: Practical Measures for Destinations. Madrid: World Tourism Organization.

World Tourism Organization and International Labour Organization (2013). Economic Crisis, International Tourism Decline and its Impact on the Poor. Madrid: UNWTO.

Yunusovich, S. S. (2018). Youth Tourism as a Scientific Research Object. Journal of Tourism \& Hospitality, 7(5), 1-3. https://doi.org/10.4172/2167-0269.1000378 